\title{
Identifying Turtle Shell Rattles in the Archaeological Record of the Southeastern United States
}

\author{
Andrew Gillreath-Brown ${ }^{1 *}$ and Tanya M. Peres ${ }^{2}$ \\ ${ }^{1}$ Department of Anthropology, Washington State University, Pullman, WA, USA. ${ }^{2}$ Department of Anthropology, Florida State \\ University, Tallahassee, FL, USA. \\ *andrew.d.brown@wsu.edu
}

\begin{abstract}
The construction of rattles from turtle (Testudines) shells is an important consideration when distinguishing between food and non-food uses of archaeological turtle remains. However, the identification of turtle shell rattles in prehistoric contexts can be quite challenging. Equifinality is a major problem for being able to distinguish rattles from food refuse, particularly when a carapace is not burnt or modified. In addition, diversity, abundance, and distribution of chelonian taxa varies throughout the southeastern United States, creating differential access for indigenous groups. Thus, multiple lines of evidence are needed from archaeological, ethnographic, and ethnohistoric records to successfully argue for the production and use of turtle shell rattles in the prehistoric southeastern United States. In this article, we present examples of turtle shell rattles in the southeastern United States to highlight their function and use by indigenous groups, the construction process, and several common characteristics, or an object trait list, that can aid in the identification of fragmentary turtle shell rattle remains. Accurate functional identification of turtle remains is important for identifying turtle shell rattle artifacts and may be of interest to indigenous groups claiming cultural items under the Native American Graves Protection and Repatriation Act (NAGPRA).
\end{abstract}

Received May 10, 2017

OPEN ӘACCESS

Accepted September 18, 2017

DOI 10.14237/ebl.8.1.2017.979

Keywords Turtle, Rattle, Terrapene carolina, Zooarchaeology, Southeastern United States, Ethnography

Copyright (C) 2017 by the author(s); licensee Society of Ethnobiology. This is an open-access article distributed under the terms of the Creative Commons Attribution-NonCommercial 4.0 International Public License (https://creativecommons.org/licenses/by-nc/4.0), which permits non-commercial use, distribution, and reproduction in any medium, provided the original author and source are credited.

Turtle or tortoise (Testudines) shell rattles are percussion instruments used by indigenous peoples in ceremonial contexts to keep rhythm and are symbols of group beliefs (Jackson and Levine 2002; Figure 1). Turtle or tortoise shell rattles occur throughout the United States, ranging from California to New York to Florida (Brown 2011). However, in this article, we concentrate on turtle shell rattles in the southeastern United States, and particularly on the difficulty of identifying turtle shell rattles in the archaeological record. They are known from archaeological, ethnographic, and ethnohistoric records of Native Americans in the southeastern United States, and remain part of Native American life among groups such as the Cherokee, Shawnee, Muscogee (Creek), Tsoyaha (Yuchi), Chickasaw, and Seminole.

Archaeological chelonian (turtles and tortoises) remains are usually assumed to be related to subsistence activities without qualifying or eliminating the possibility of their being a turtle shell rattle or other turtle shell artifact (e.g., bowl, cup, or effigy). Further, equifinality is a major contributor to the identification issue surrounding fragmentary turtle remains (Lyman 2004). Several types of activities, such as food preparation or rattle construction, could lead to the same taphonomic state-similar looking turtle shell specimens. Therefore, we integrate information about turtle shell rattles from ethnographic and ethnohistoric accounts of turtle shell rattle use and archaeological occurrences of turtle rattles to give researchers a foundation for evaluating fragmentary turtle remains and understanding turtle shell rattles in archaeofaunal samples in the southeastern United States. Proper identification of chelonian remains is important for data quality and archaeological interpretation. Since turtle shell rattles are generally associated with ritual, ceremonial, and mortuary activity, proper identification is important for indigenous groups, who may be able to claim cultural items under the Native Ameri- 

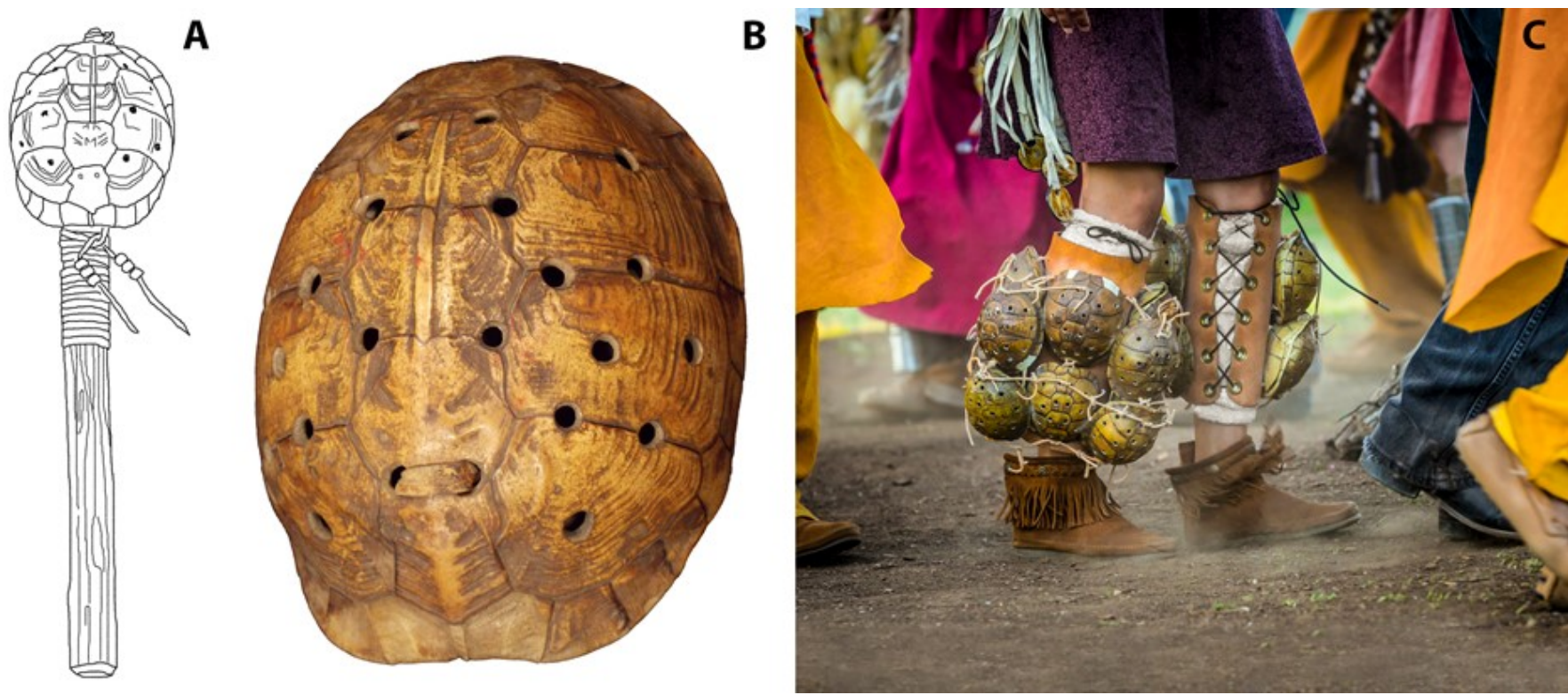

Figure 1 Examples of two types of turtle shell rattles. A Parallel handheld rattle. Figure produced by Bailey Gillreath-Brown. B Historic body rattle. Courtesy McClung Museum of Natural History and Culture, University of Tennessee, Knoxville, Tennessee. Photo by Andrew Gillreath-Brown. C Chickasaw turtle shell leg shakers. Image by the Chickasaw Nation Department of Communications and Community Development (1994). All rights reserved. For permissions and other rights under this copyright, contact the Chickasaw Nation.

can Graves Protection and Repatriation Act (NAGPRA).

In the southeastern United States, indigenous groups exploited and used a diverse range of chelonian taxa, including, but not limited to, eastern or common box turtle (Terrapene carolina), ornate or western box turtle (T. ornata), common or North American snapping turtle (Chelydra serpentina), mud turtles (Kinosternon spp.), musk turtles (Sternotherus spp.), river cooter (Pseudemys concinna), eastern painted turtle (Chrysemys picta picta), pond or common slider (Trachemys scripta), and softshell turtles (Apalone spp.) ${ }^{1}$. However, southeastern indigenous groups would have had differential access to any given taxa, depending on the distribution and availability within their local environments, though trading is also a possibility. Therefore, some indigenous groups would have had an easier time collecting turtles for rattle construction.

Through a review of several ethnographic and archaeological cases, we developed an object trait list of five common characteristics of rattle manufacturing that can be used to distinguish turtle shell rattles from subsistence remains, including: ceremonial, ritual, or burial association; turtle species preference; carapace and plastron representation; modifications; and rattle implements (Brown 2011). Rattle forms in the southeastern United States include parallel handheld and body (or shackle) types (Figure 1). Rattles are commonly constructed from eastern box turtle (T. c. carolina) shells.

The ethnographic record gives in-depth information on crafting rattles, the function of rattles, and representative examples of the object trait list. The Shawnee, Cherokee, and Absentee of Oklahoma and the Eastern Band of Cherokee used turtle shells to craft parallel handheld rattles that relate to magical songs, typically sung by a male shaman (Dodd 2002:13 -14; Voegelin 1942; Figure 1A). The rattles were also used by Cherokee Shawnee False Face impersonators. False faces were people that led dances and would use turtle shell rattles to help stave off disease and protect houses (Voegelin 1942:467). Voegelin (1942:467) describes the "tortoise shell hand rattles" as using a wood turtle (Glyptemys insculpta) for rattle construction; however, this species is found in the northeast United States. In the ethnographic literature, "tortoise" is sometimes used for T. carolina spp. (e.g., Parker 1909:79), as they appear tortoise-like (Turtle Extinctions Working Group 2015:16). To prepare the rattle, the turtle was boiled in water, the inside of the turtle shell cleaned out, and the plastron and carapace were sun dried, enabling the carapace and plastron to 
Table 1. Description and interpretation of turtle shell rattle object traits and relationship to turtle remains.

\begin{tabular}{|c|c|}
\hline Object Trait ${ }^{*}$ & Description and Interpretation \\
\hline $\begin{array}{l}\text { Ceremonial, ritual, or burial } \\
\text { association }\end{array}$ & $\begin{array}{l}\text { Rattles are used in ceremonies and rituals that include many dances. Rattles are interred } \\
\text { in burials, possibly with the people that used them in the ceremonies and rituals. Howev- } \\
\text { er, turtle shell specimens found in ceremonial and ritual contexts could also be a result of } \\
\text { ritual feasting }{ }^{* *} \text {. }\end{array}$ \\
\hline Turtle species preference & $\begin{array}{l}\text { T. carolina is the preferred and dominant chelonian taxon for rattle construction in the } \\
\text { southeastern United States. It is unclear whether box turtles can be consumed, since they } \\
\text { consume mushrooms that are poisonous to humans (Brown 2011:4). }\end{array}$ \\
\hline $\begin{array}{l}\text { Carapace and plastron repre- } \\
\text { sentation }\end{array}$ & $\begin{array}{l}\text { Only the carapace and plastron are used in rattle construction. In a subsistence context, } \\
\text { there would be a broader range of skeletal representation. }\end{array}$ \\
\hline Modification & $\begin{array}{l}\text { Rattles are intentionally (e.g., drilling) and unintentionally (e.g., stress striations or polish) } \\
\text { modified (Brown 2011:10-11). Drilling is the most common rattle modification and has at } \\
\text { least two functions, allowing sound to exit the container and cordage to pass through the } \\
\text { holes so that the shell can be tied to the arm or leg, or attached to animal skin (hide). } \\
\text { Some modifications, such as drilling, polish, stress-striations (from use), and wear from } \\
\text { rattle objects, cordage, clothing, body, or hide, might be evidence of rattles. In contrast, } \\
\text { other modifications, such as cut marks, scoring and snapping, butchery, and thermal alter- } \\
\text { ation, might be associated with food remains. }\end{array}$ \\
\hline Rattle implements & $\begin{array}{l}\text { Pebbles, freshwater drum (Aplodinotus grunniens) molariform teeth, and seeds are a few } \\
\text { of the implements used in rattles to create the signature rattle sound. The implements are } \\
\text { sometimes found in direct association with turtle shells. However, due to taphonomic } \\
\text { issues, the implements may preserve but not the turtle specimen. Further, some imple- } \\
\text { ments may be discarded in excavations. }\end{array}$ \\
\hline
\end{tabular}

*When evaluating turtle shell specimens, we recommend that multiple traits be present to make the case that a given specimen functioned as a rattle instead of for food.

${ }^{* *}$ Individual traits can also be used to further evaluate another trait. For example, to distinguish between rattles (or another turtle artifact) and feasting, turtle species preference and skeletal representation could be used to understand whether a species would have been eaten and whether the skeletal elements represented a closer association with rattle or food deposition.

remain in one piece (Voegelin 1942). Holes were then drilled around the edges so that buckskin could be used to tie the carapace and plastron together. The rattle implements, typically quartz crystals or small rocks, were placed inside of the shell. Next, a roundpiece of wood, which was tapered at one end, was inserted through the bottom to the top, then a wooden peg was fitted around the top tapered end (Figure 1A).

Shawnee, Cherokee, and Absentee of Oklahoma used Terrapene spp. to create body rattles or shackles, which are used by younger women, as opposed to the handheld rattles that are used by mostly men (Brown 2011; Jackson and Levine 2002; Voegelin 1942; Figure 1B-1C). The body rattle has been associated with various ceremonies and dances, such as the Garfish
Dance, Green Corn Ceremony, Ribbon Dance, and the Stomp Dance (Dodd 2002:14; Howard 1968:90; Jackson and Levine 2002). Body turtle shell rattles can be tied directly to the arm or leg with cordage; thus, the shells may or may not have holes drilled in the carapace and plastron (Brown 2011:Figure 12; Figure 1B). In the southeastern United States, Chickasaw, Cherokee, Muscogee (Creek), and Tsoyaha (Yuchi) women tied together six to ten rattles made from T. $c$. carolina shells (Fradkin 1990:424; Speck 1911). These were attached to a piece of hide, such as deer (Odocoileus spp.) or woodchuck (Marmota monax), that was then fastened to the dancer's legs (Figure 1C). These are sometimes called shackles or leggings. Since the turtle shells were tied together and then attached to hide, the shells had drilled holes. Pebbles, freshwa- 
ter drum (Aplodinotus grunniens) molariform teeth, or possibly other small implements like seeds, were placed inside to create the signature rattle sound when shaken (Brown 2011). James Adair (1775) provides one of the earliest rattle accounts, probably about the Chickasaw, with whom Adair had begun trading with in 1744. Adair $(1775: 97,170)$ describes the rattles as small shells filled with white pebbles or beads and tied to a piece of white deerskin, then tied to each leg, which were worn by women.

Archaeologically recovered rattles mainly occur in the traditional homelands of indigenous groups known from ethnographic and ethnohistoric records. For example, rattles were discovered at the Warren Wilson and Coweeta Creek sites in southwestern North Carolina (Rodning and Moore 2010), homeland of the Cherokee and close to the Muscogee (Creek) and Tsoyaha (Yuchi). Turtle shell body rattles have been recovered from archaeological contexts throughout the southeastern United States (Brown 2011; Lewis and Kneberg 1970). The body rattles have three to five holes drilled into the shell, which allows for the shell to be tied to the arm or leg (Brown 2011:Figure 2; Lewis and Kneberg 1970:126127). It is unclear whether prehistoric rattles may have been bundled together and attached to a material like hide. However, the presence of many turtle shell rattles in single burials suggests a legging style design. A woman in Burial 7 at the Hiwassee Island site in Tennessee may have worn the turtle shell rattle leggings. Excavators noted ten turtle shell rattles at her legs (Lewis and Kneberg 1970:126-127). However, in Burial 89, the turtle shell rattles were positioned around both upper arms of a young female (Lewis and Kneberg 1970:148).

Archaeologically, complete or near-complete turtle shell rattles are known from mortuary associations, though fragmentary turtle remains are rarely identified as anything other than food waste. Therefore, the question is whether fragmentary turtle remains represent food, rattles, other types of artifacts, or even a combination of uses. Fragmentary turtle remains often have no signs of modification associated with food preparation (e.g., burning or butchering), making the presence of turtle specimens in archaeofaunal assemblages difficult to interpret. Other problems stem from the amount of turtle fragments at archaeological sites. The number of identified specimens (NISP) can be very high for turtle remains, which stems from how easily turtle specimens are disarticulated. Further, while elements can be easily identified, interdependence can still be a major issue. Contexts with a broad range of skeletal parts may be more likely to represent discarded subsistence remains; however, the refuse could be from rattle preparation. In that case, according to the object trait list above, the carapace and plastron would not be present since they would be used in rattle construction. Rattle implements are also subjected to biases (Brown 2011). River pebbles may have been discarded as soil during excavations and seeds may not have preserved in the archaeological record.

Dietary turtle remains and turtle shell rattles cooccur at archaeological sites; however, differences in context may provide some insights into the mode of turtle shell deposition. Coweeta Creek is a late prehistoric and protohistoric settlement located in Macon County, southwestern North Carolina. For general turtle remains at the site, VanDerwarker and Detwiler (2000) report a NISP of 297, including 113 unidentifiable turtle, and an MNI of 19 for T. carolina, K. subrubrum (eastern or common mud turtle), and $C$. serpentina, which were recovered from pit features, townhouse floors, and mound fill. Various turtle elements (e.g., humerus, dentary, vertebra, scapula, pubis, and femora) were discovered in different contexts such as pit features and structure floors; further, about 27 carapace/plastron fragments were burned or calcined. Turtle shell rattles were mostly confined to burials and only consisted of carapace and plastron elements; however, above floor 5 of the Coweeta Creek townhouse mound, a $T$. carolina carapace fragment had a drilled hole and was polished. The townhouse is public architecture and may have also been a place for public ritual (Rodning and VanDerwarker 2002). Three turtle shell rattles were discovered at the site in two burials of young adult women, of which the rattles had associated pebbles ${ }^{2}$ Given that rattles are predominantly associated with burial, ceremonial, and ritual contexts (and possibly a public ritual space), the co-occurrence at the site highlights the differences in context between dietary and rattle remains.

Research focusing on turtle shell rattles represents an overlooked research topic in archaeology and zooarchaeology. However, by using multiple lines of evidence from zooarchaeological data, the object trait list (ceremonial, ritual, or burial association; turtle species preference; carapace and plastron representation; modifications; and rattle implements), ethno- 
graphic and ethnohistoric data, and other studies, turtle shell rattles can be successively identified in the archaeological record in the southeastern United States (Table 1). Further, with a firm quantitative and qualitative base, we can begin to have substantial discussions on the functions of turtle shells as rattles and their potential to be claimed under NAGPRA.

\section{Notes}

${ }^{1}$ The geographic distribution of different turtle species can be accessed through the IUCN Red List (http:// www.iucnredlist.org/). Also, see Turtle Taxonomy Working Group [P. P. van Dijk, J. B. Iverson, A. G. J. Rhodin, H. B. Shaffer, and R. Bour]. 2014. Turtles of the World, 7th Edition: Annotated Checklist of Taxonomy, Synonymy, Distribution with Maps, and Conservation Status. In Conservation Biology of Freshwater Turtles and Tortoises: A Compilation Project of the IUCN/ SSC Tortoise and Freshwater Turtle Specialist Group. Chelonian Research Monographs 5(7):000.329-479, edited by A. G. J. Rhodin, P. C. H. Pritchard, P. P. van Dijk, R. A. Saumure, K. A. Buhlmann, J. B. Iverson, and R. A. Mittermeier. DOI:10.3854/ crm.5.000.checklist.v7.2014.

${ }^{2}$ From visual examination of an image of the Burial 43 turtle shell rattle, it is possible that the rattle had at least one drilled hole, but the remains were not wellpreserved and have now been repatriated (https:// rla.lib.unc.edu/rla/record/91485/context/specimen). Source: Research Laboratories of Archaeology, University of North Carolina, Chapel Hill, North Carolina.

\section{Acknowledgements}

We are grateful to Dr. Christopher B. Rodning for additional information on the Coweeta Creek burials and turtle shell rattles. We are thankful to Dr. Amber M. VanDerwarker for providing and answering questions about the Coweeta Creek faunal data. We thank Dr. R. P. Stephen Davis Jr. and the Research Laboratories of Archaeology, University of North Carolina, Chapel Hill, NC, for providing additional documentation on the Coweeta Creek burials that helped better inform the rattles. We thank the Chickasaw Nation for allowing us to use their image. The authors gratefully acknowledge the EBL editors and production and editorial assistant, and three anonymous reviewers for their very constructive comments. However, any omissions or errors are the authors'.

\section{Declarations}

Permissions: Bailey Gillreath-Brown gave permission to use Figure 1A. McClung Museum of Natural History and Culture granted permission to use GillreathBrown's photo in Figure 1B. The Chickasaw Nation granted permission to use their image in Figure 1C.

Sources of funding: This research was funded in part by a 2011 Undergraduate Research Experience and Creative Activity (URECA) Grant (Account \#224500) through the Undergraduate Research Center at Middle Tennessee State University.

Conflicts of Interest: None declared.

\section{References Cited}

Adair, J. 1775. The History of the American Indians. Edward and Charles Dilly, London, United Kingdom.

Brown, A. 2011. An Exploration of Turtle Shell Rattle Manufacture in the Mississippian Period. Anthropology Senior Thesis, Department of Sociology and Anthropology, Middle Tennessee State University, Murfreesboro, TN. DOI:10.13140/

RG.2.1.2675.5921.

Dodd, C. K. 2002. North American Box Turtles: A Natural History. University of Oklahoma Press, Norman, OK.

Fradkin, A. 1990. Cherokee Folk Zoology: The Animal World Native American People (1700-1838). Garland Publishing, New Haven, CT.

Howard, J. H. 1968. The Southeastern Ceremonial Complex and Its Interpretation. Missouri Archaeological Society, Memoir 6, Columbia, MO.

Jackson, J. B., and V. L. Levine. 2002. Singing for Garfish: Music and Woodland Communities in Eastern Oklahoma. Ethnomusicology 46:284-306. DOI:10.2307/852783.

Lewis, T., and M. Kneberg. 1970. Hiwassee Island: An Archaeological Account of Four Tennessee Indian Peoples. University of Tennessee Press, Knoxville, TN.

Lyman, R. L. 2004. The Concept of Equifinality in Taphonomy. Journal of Taphonomy 2:15-26.

Parker, A. C. 1909. Secret Medicine Societies of the Seneca. American Anthropologist 11:161-185. DOI:10.1525/aa.1909.11.2.02a00010.

Rodning, C. B., and D. G. Moore. 2010. South Appalachian Mississippian and Protohistoric Mortuary Practices in Southwestern North Carolina. 
Southeastern Archaeology 29:80-100. DOI:10.1179/ sea.2010.29.1.006.

Rodning, C. B., and A. M. VanDerwarker. 2002. Revisiting Coweeta Creek: Reconstructing Ancient Cherokee Lifeways in Southwestern North Carolina. Southeastern Archaeology 21:1-9.

Speck, F. G. 1911. Ceremonial Songs of the Creek and Yuchi Indians. University of Pennsylvania, The Museum of Anthropological Publications, Vol. 1, No. 1. University Museum, Philadelphia, PA.

Turtle Extinctions Working Group [A. G. J. Rhodin, S. Thomson, G. Georgalis, H. V. Karl, I. G. Danilov, A. Takahashi, M. S. de la Fuente, J. R. Bourque, M. Delfino, R. Bour, J. B. Iverson, H. B. Shaffer, and P. P. van Dijk]. 2015. Turtles and Tortoises of the World During the Rise and Global Spread of Humanity: First Checklist and Review of
Extinct Pleistocene and Holocene Chelonians. In Conservation Biology of Freshwater Turtles and Tortoises: $A$ Compilation Project of the IUCN/SSC Tortoise and Freshwater Turtle Specialist Group. Chelonian Research Monographs 5(8):000e.1-66, edited by A. G. J. Rhodin, P. C. H. Pritchard, P. P. van Dijk, R. A. Saumure, K. A. Buhlmann, J. B. Iverson, and R. A. Mittermeier. DOI:10.3854/

crm.5.000e.fossil.checklist.v1.2015.

VanDerwarker, A. M., and K. R. Detwiler. 2000. Plant and Animal Subsistence at the Coweeta Creek Site (31MA34), Macon County, North Carolina. North Carolina Archaeology 49:59-77.

Voegelin, E. W. 1942. Shawnee Musical Instruments. American Anthropologist 44:463-475. DOI:10.1525/ aa.1942.44.3.02a00110. 